\title{
PENGUATAN BEA CUKAI SECARA KELEMBAGAAN DALAM MENGHADAPI KEJAHATAN TRANSNASIONAL
}

\author{
Oleh : \\ Milyan Risydan Al Anshori, S.H., M.H. \\ Mahasiswa Program Doktor Ilmu Hukum UNTAG Semarang, \\ email:milyansay@gmail.com.
}

\begin{abstract}
Abstrak
Kejahatan transnasional adalah kejahatan yang sarana prasarana serta metode-metode yang dipergunakan melampaui batas territorial suatu negara. Namun demikian belum ada perhatian khusus dari pemerintah untuk menghadapi jenis kejahatan ini dengan menggunakan bea cukai. Padahal jika sarana prasarana dan metode kejahatannya melampaui batas territorial maka sudah otomatis alat bukti dan barang bukti pun melintasi daerah pabean. Karena itu bisa diambil kesimpulan sementara bahwa perlu optimalisasi kewenangan dan tanggung jawab lembaga bea cukai untuk lebih aktif menangkal serangan kejahatan transnasional ini.
\end{abstract}

Kata kunci: kejahatan transnasional, kepabeanan, kewenangan, kelembagaan.

\section{STRENGTHENING INDONESIA CUSTOMS INSTITUTION \\ IN ORDER TO AGAINST TRANSNATIONA CRIME}

\author{
Oleh : \\ Milyan Risydan Al Anshori, S.H., M.H. \\ Mahasiswa Program Doktor Ilmu Hukum UNTAG Semarang, \\ email: milyansay@gmail.com.
}

\begin{abstract}
Transnational crime is a crime which is the tools and methods that is being used is pass through national territorial border. However, there's no sufficient attention from goverment to fight againts this kind of crime by using customs. Even though if the tools and methods have already passed through territorial border so the proof and evidence have passed it too. Due to it, we can take temporary conclutions that the authority and responsibility of customs institution need to be optimalized in order to prevent this transnational crime attack.
\end{abstract}

Keywords: transnational crime, customs, authority, institution. 


\section{Pendahuluan}

\section{A. Latar Belakang (Kesenjangan)}

Dalam beberapa tahun terakhir, muncul kejahatan-kejahatan yang beraspek internasional yang disebut sebagai kejahatan transnasional (transnational crime). Istilah transnasional sendiri dalam kepustakaan hukum internasional pertama kali diperkenalkan oleh Phillip C. Jessup. Jessup menjelaskan bahwa selain istilah hukum internasional atau international law, digunakan pula istilah hukum transnasional atau transnasional law yang dirumuskan, semua hukum yang mengatur semua tindakan atau kejadian yang melampaui batas territorial suatu Negara. ${ }^{1}$ Kejahatan transnasional merupakan bagian dari kejahatan internasional yang mempunyai dampak melewati batas territorial suatu Negara, kejahatan transnasional dapat dilakukan secara individual dan/atau kelompok atau terorganisir.

Kejahatan transnasional yang terorganisir diatur dalam Convention of Transnational Organized Crime 2000 atau yang biasa disebut dengan Konvensi Palermo 2000. Pengertian istilah transnational crime digunakan dalam salah satu Keputusan Kongres PBB ke VIII, tentang Pencegahan Kejahatan dan Perlakuan terhadap para Pelanggar Hukum tahun 1990, dan digunakan dalam Konvensi Wina tentang Pencegahan dan Pemberantasan Lalu Lintas Ilegal Narkotika dan Psikotropika tahun 1988. Pengertian istilah tersebut terakhir digunakan dalam Konvensi PBB Anti Kejahatan Transnasional Terorganisasi tahun 2000.

\section{Menurut United Nations Convention} on Transnational Organized Crime tahun 2000 , kejahatan bisa disebut bersifat transnasional

Romli Atmasasmita, Tindak Pidana Narkotika Transnasional dalam Sistem Hukum Pidana Indonesia, Bandung: Citra Aditya Bhakti, 1997, hlm 27 jika: ${ }^{2}$

1. Dilakukan di lebih dari satu negara,

2. Persiapan, perencanaan, pengarahan dan pengawasan dilakukan di negara lain,

3. melibatkan organized criminal group (organisasi kriminal) dimana kejahatan dilakukan di lebih satu negara,

4. berdampak serius pada negara lain.

Kejahatan transnasional merupakan fenomena sosial yang melibatkan orang, tempat dan kelompok, yang juga dipengaruhi oleh berbagai sosial, budaya, faktor ekonomi. Akibatnya, berbagai negara cenderung memiliki definisi kejahatan transnasional yang sangat berbeda tergantung pada filosofi tertentu. ${ }^{3}$

Pada sisi lain, Direktorat Jenderal Bea dan Cukai adalah adalah unsur pelaksana tugas pokok dan fungsi Kementerian Keuangan di bidang kepabeanan dan cukai. Sedangkan kepabeanan adalah Kepabeanan adalah "segala sesuatu yang berhubungan dengan pengawasan atas lalu lintas barang yang masuk atau keluar daerah pabean serta pemungutan bea masuk dan bea keluar". Daerah pabean sendiri didefinisikan sebagai "wilayah Republik Indonesia yang meliputi wilayah darat, perairan dan ruang udara di atasnya, serta tempat-tempat tertentu di Zona Ekonomi Eksklusif dan landas kontinen yang di dalamnya berlaku UU No. 10 tahun 1995 stdd $^{4}$ UU No. 17 Tahun 2006 Tentang Kepabeanan". Artinya Direktorat Jenderal Bea dan Cukai adalah unsur pelaksana tugas pokok dan fungsi Kementerian Keuangan yang berwenang menangani "segala sesuatu yang berhubungan dengan pengawasan atas lalu lintas barang yang masuk atau keluar wilayah Republik Indonesia yang meliputi wilayah darat, perairan dan ruang udara

\footnotetext{
2 Romli Atmasasmita, Pengantar Hukum Pidana Internasional. Bandung: PT. Eresco, 1995, Hlm. 5 Oentoeng Wahjoe, Perkembangan Tindak Pidana Internasional dan Proses Penegakannya, Jakarta:Penerbit Erlangga; Jakarta, 2011, hlm. 30 Sebagaimana telah diubah dengan.
} 
di atasnya, serta tempat-tempat tertentu di Zona Ekonomi Eksklusif dan landas kontinen".

Kenyataannya Direktorat Jenderal Bea dan Cukai nampaknya dipandang belum cukup berperan dalam hal tersebut. Hal itu dibuktikan dengan adanya BPHN dalam "LAPORAN AKHIR KOMPENDIUM ${ }^{5}$ HUKUM TENTANG KERJASAMA INTERNASIONAL DI BIDANG PENEGAKAN HUKUM TAHUN 2012", yang menyebutkan bahwa setidaknya ada beberapa lembaga yang berwenang dan/atau dapat diberi kewenangan untuk mengatasi kejahatan transnasional yaitu: ${ }^{6}$

1. POLRI

2. Interpol/POLRI

3. Angkatan Laut

4. Badan Koordinasi Kemanan Laut (BAKORKAMLA)

5. Kejaksaan Agung

6. KPK

7. PPATK

8. BPK

9. BNPT

10. Kemenkopolhukam

11. Kementerian Luar Negeri

12. Badan Intelijen Negara

13. Pemerintah Daerah

Dari ketiga belas nama lembaga yang disebutkan oleh BPHN tersebut tidak terdapat Kementerian Keuangan c.q. Direktorat Jenderal Bea dan Cukai. Artinya bisa jadi memang ada persepsi bahwa Bea Cukai tidak berwenang atau bahkan tidak berperan dalam usaha nasional mengatasi kejahatan transnasional.

Padahal jika dilihat dari definisi

$5 \quad$ ikhtisar karangan ilmiah yang lengkap dan padat, kamus besar bahasa indonesia.

6 BPHN, Laporan Akhir Kompendium Hukum tentang Kerja Sama Internasional di Bidang Penegakan Hukum, Jakarta: BPHN, 2012, Hlm. 15. kejahatan transnasional menurut United Nations Convention on Transnational Organized Crime tahun 2000, kejahatan bisa disebut bersifat transnasional jika: ${ }^{7}$

1. Dilakukan di lebih dari satu negara,

2. Persiapan, perencanaan, pengarahan dan pengawasan dilakukan di negara lain,

3. melibatkan organized criminal group (organisasi kriminal) dimana kejahatan dilakukan di lebih satu negara,

4. berdampak serius pada negara lain.

Maka nampak jelas terlihat bahwa ada aspek kepabeanan pada kejahatan transnasional yaitu pelintasan batas negara. Karenanya tidak melibatkan bea cukai dalam pemberantasan kejahatan transnasional bisa berdampak kontra produktif bagi penegakan hukum itu sendiri.

Secara konsep, transnational crime merupakan tindak pidana atau kejahatan lintas batas dan diperkenalkan pertama kali secara internasional pada era 1990-an saat pertemuan bangsa-bangsa yang membahas pencegahan kejahatan. Di tahun 1995, PBB telah mengindetifikasi 18 jenis kejahatan transnasional yaitu money laundering (pencucian uang), terrorism (terorisme), theft of art and cultural objects (pencurian objek seni dan kebudayaan), theft of intellectual property (pencurian karya intelektual), illicit arms trafficking (perdagangan gelap tentara dan senjata), aircraft hijacking (pembajakan pesawat), sea piracy (bajak laut), insurance fraud (penipuan), computer crime (kejahatan cyber), environmental crime (kejahatan terhadap lingkungan), trafficking in persons (penyelundupan manusia), trade in human body parts (perdagangan bagian tubuh manusia), illicit drug trafficking (penyelundupan obat bius), fraudulent bankruptcy (kecurangan), infiltration of legal business (penyusupan bisnis legal), corruption (korupsi), bribery of public (penyogokan

\footnotetext{
7 Romli Atmasasmita, Pengantar Hukum Pidana Internasional. Bandung: PT. Eresco, 1995, Hlm. 51
} 
pejabat publik), dan bribery of party officials (penyogokan pejabat partai) ${ }^{8}$.

Uniknya meskipun kejahatan transnasional adalah kejahatan yang sarana prasarana serta metode-metode yang dipergunakan melampaui batas territorial suatu negara, belum ada perhatian khusus dari pemerintah untuk menghadapi kejahatan ini dengan menggunakan bea cukai. Padahal jika sarana prasarana dan metode kejahatannya melampaui batas territorial maka sudah otomatis alat bukti dan barang bukti pun melintasi daerah pabean. Karena itu bisa diambil kesimpulan sementara bahwa perlu optimalisasi kewenangan dan tanggung jawab bea cukai untuk lebih aktif menangkal serangan kejahatan transnasional ini.

Sebagaimana telah kita ketahui bersama ${ }^{9}$ bahwa Direktorat Jenderal Bea dan Cukai hanyalah salah satu unit eselon I di lingkungan Kementerian Keuangan. Direktorat Jenderal Bea dan Cukai adalah unsur pelaksana tugas pokok dan fungsi Departemen Keuangan di bidang kepabeanan dan cukai. Kebutuhan akan dibeking langsung oleh Presiden disampaikan langsung oleh Dirjen Bea Cukai merupakan indikasi adanya harapan dari Ditjen Bea Cukai agar ada penguatan struktur kelembagaan yang lebih memadai dalam pelaksanaan wewenang yang sedemikian vital terutama terkait dengan gesekan-gesekan di lapangan dalam pelaksanaan tugas.

Menurut kamus besar bahasa Indonesia, penguatan adalah kata benda yang bermakna proses, cara, perbuatan menguati atau menguatkan. Artinya penguatan adalah suatu upaya membuat kuat atau lebih

8 Buletin Berkala LPSK Edisi No. III Tahun 2012. Hlm. 4 9 Meskipun kehadiran Bea Cukai tidak betul-betul telah dipahami secara benar oleh masyakat umum, namun mengingat ketentuan keberadaan (eksistensi) Bea Cukai dicantumkan dalam undang-undang yang telah diberitakan dalam lembaran negara maka berdasarkan teori fiksi, masyarakat Indonesia (baik warga negara Indonesia atau non warga Negara Indonesia) dianggap telah mengetahuinya kuat dari kondisi sebelumnya. Penguatan dalam tesis ini adalah dalam konteks hukum administrasi negara. Oleh karena itu penguatan yang disasar adalah penguatan lembaga baik pada struktur kelembagaan maupun pada kewenangan.

Berdasarkan uraian tersebut diatas, maka penulis mengambil judul Penulisan Karya Ilmiah yang berupa tesis ini, "PENGUATAN BEA CUKAI SECARA KELEMBAGAAN DALAM MENGHADAPI KEJAHATAN TRANSNASIONAL".

\section{B. Perumusan Masalah}

Bagaimana pelaksanaan penegakan hukum oleh Bea Cukai terkait kejahatan transnasional?

\section{Metode Penelitian}

Metode penelitian yang digunakan pada penelitian ini adalah yuridis normatif. Penelitian ini disebut penelitian yuridis normatif karena kami memposisikan ketentuan hukum sebagai premis mayor. Hal tersebut berbeda dengan metode penelitian hukum yuridis empiris yang memposisikan fakta empiris sebagai premis mayor. Pengumpulan data pada penelitian ini menggunakan metode studi pustaka dengan bahan hukum primer sebagai acuan utama.

\section{Hasil dan Pembahasan}

\section{A. Pelaksanaan Penegakan Hukum oleh Bea} Cukai terkait kejahatan transnasional

Penegakan hukum yang dilakukan oleh bea cukai dalam rangka melawan kejahatan transnasional erat kaitannya dengan fungsi bea cukai selaku pemangku amanat undang-undang kepabeanan. Hal tersebut karena Direktorat Jenderal Bea dan Cukai adalah unsur pelaksana tugas pokok dan fungsi Kementerian Keuangan di bidang kepabeanan dan cukai. Sedangkan kepabeanan adalah Kepabeanan adalah "segala sesuatu yang berhubungan dengan 
pengawasan atas lalu lintas barang yang masuk atau keluar daerah pabean serta pemungutan bea masuk dan bea keluar". Daerah pabean sendiri didefinisikan sebagai "wilayah Republik Indonesia yang meliputi wilayah darat, perairan dan ruang udara di atasnya, serta tempat-tempat tertentu di Zona Ekonomi Eksklusif dan landas kontinen yang di dalamnya berlaku UU No. 10 tahun 1995 stdd UU No. 17 Tahun 2006 Tentang Kepabeanan". Artinya Direktorat Jenderal Bea dan Cukai adalah unsur pelaksana tugas pokok dan fungsi Kementerian Keuangan yang berwenang menangani "segala sesuatu yang berhubungan dengan pengawasan atas lalu lintas barang yang masuk atau keluar wilayah Republik Indonesia yang meliputi wilayah darat, perairan dan ruang udara di atasnya, serta tempat-tempat tertentu di Zona Ekonomi Eksklusif dan landas kontinen".

Pelaksanaan penegakan hukum oleh bea cukai dilakukan dengan 2 cara yaitu melalui pengawasan dan pelayanan. Pengawasan adalah upaya aktif petugas untuk memastikan bahwa ketentuan kepabeanan telah dipenuhi. Adapun pelayanan adalah upaya petugas untuk melayani upaya para subjek hukum untuk memenuhi kewajiban hukumnya. Karena melayani adalah suatu kegiatan yang timbul bila ada kepentingan dari pihak yang dilayani maka kegiatan pelayanan senantiasa cenderung pasif.

Pengawasan bisa dimaknai secara umum atau secara khusus. Secara umum, pengawasan adalah segala sesuatu yang dilakukan dalam rangka memastikan dan menjamin terpenuhinya ketentuan undang-undang kepabeanan. Pengawasan kepabeanan secara khusus adalah dilakukan dengan cara intelijen, penindakan dan penyidikan.

Pelayanan kepabeanan dilakukan dengan 2 cara yaitu kegiatan pelayanan dalam rangka impor dan dalam rangka ekspor. Kegiatan pelayanan dalam rangka impor adalah untuk melayani kegiatankegiatan untuk memasukan barang ke dalam daerah pabean. Adapun kegiatan pelayanan ekspor adalah kegiatan pelayanan untuk mengeluarkan barang ke luar daerah pabean.

\section{a. Impor}

Impor adalah kegiatan yang sangat dikenal oleh masyarakat umum. Namun ada perbedaan pengertian antara impor dalam konteks ekonomi bisnis dan impor menurut hukum kepabeanan Indonesia. Impor dalam konteks ekonomi bisnis adalah membeli barang dari luar negeri. ${ }^{10}$ Namun pada kenyataannya untuk mendapatkan barang impor tidaklah selalu menggunakan cara membeli. Hal-hal lain yang bisa mengakibatkan timbulnya kepemilikan barang impor adalah hibah, meminjam, menyewa dan berbagai hubungan perikatan perdata lainnya. Oleh karena itu dalam hukum kepabeanan Indonesia, Impor didefinisikan sebagai suatu kegiatan memasukkan barang ke dalam daerah pabean $^{11}$. Penekanannya adalah pada kegiatan memasukan ${ }^{12}$ yang berarti terjadi pelintasan ke dalam daerah pabean.

Ada banyak tujuan dan alasan seseorang (atau badan hukum) melakukan kegiatan pengimporan. Namun hukum kepabeanan tidak menyoroti apa motif dan tujuan pribadi-pribadi melakukan impor. Hukum kepabeanan Indonesia mengklasifikasi tujuan impor menurut proses kegiatan selanjutnya sebagai konsekuensi dari impor

\footnotetext{
10 Pengalaman pribadi peneliti, sejak belajar di SD, pengertian bahwa impor adalah membeli barang dari luar negeri.

11 Daerah pabean adalah wilayah Republik Indonesia yang meliputi wilayah darat, perairan dan ruang udara di atasnya, serta tempat-tempat tertentu di Zona Ekonomi Eksklusif dan landas kontinen yang di dalamnya berlaku Undang-Undang ini (Pasal 1 angka 2 Undang-Undang Nomor 17 Tahun 2006 Tentang Perubahan UndangUndang Nomor 10 Tahun 1995 Tentang Kepabeanan).

12 Menurut kamus besar Bahasa indonesia, memasukan berarti membuat menjadi masuk.
} 
tersebut. Tujuan-tujuan impor menurut hukum kepabeanan Indonesia adalah sebagai berikut:

a. diimpor untuk dipakai;

b. diimpor sementara;

c. ditimbun di tempat penimbunan berikat;

d. diangkut ke tempat penimbunan sementara di kawasan pabean lainnya;

e. diangkut terus atau diangkut lanjut; atau

f. diekspor kembali.

Dari ke enam tujuan tersebut sebetulnya impor dapat diklasifikasi menjadi 2 saja yaitu impor yang betul-betul impor dan impor yang bukan impor. Impor yang betul-betul impor memenuhi kaidah hukum materiil dan formil. Adapun impor yang bukan impor adalah impor yang hanya memenuhi kaidah formil saja.

Impor yang bukan impor tersebut adalah impor dengan tujuan diangkut lanjut atau diangkut terus atau diekspor kembali. Yang dimaksud dengan impor barang untuk diangkut terus yaitu kegiatan importasi barang yang diangkut dengan sarana pengangkut melalui kantor pabean tanpa dilakukan pembongkaran terlebih dulu. Adapun yang dimaksud dengan impor barang diangkut lanjut yaitu kegiatan importasi barang yang diangkut dengan sarana pengangkut melalui kantor pabean dengan dilakukan pembongkaran terlebih dulu. Hal itu wajar saja karena seringkali dalam sarana pengangkut terdapat muatan-muatan yang sebenarnya tidak hendak ditujukan ke wilayah yang disinggahi sementara. Karena persoalan teknis penataan susunan muatan, bisa saja suatu muatan terpaksa harus dibongkar dahulu ${ }^{13}$ sebelum melanjutkan perjalanan keluar dari dalam daerah pabean ke luar daerah pabean. Hal itulah yang kemudian disebut diangkut lanjut karena

13 Barang sempat menjejak/mendarat turun dari sarana pengangkut. Jika barang dibongkar dalam sarana pengangkut tanpa ke luar sarana pengangkut maka disebut diangkut terus. sempat ada interupsi pembongkaran. Adapun muatan yang tetap berada di dalam sarana pengangkut ketika muatan sarana pengangkut dibongkar disebut diangkut terus karena terus-terusan berada di dalam sarana pengangkut tanpa sempat disela oleh pembongkaran. ${ }^{14} \mathrm{Hal}$ tersebut ada kaitannya dengan kaidah hukum yang menyatakan bahwa kapal atau kapal udara adalah bagian dari suatu negara dan berlaku ketentuan hukum negara asal kapal atau kapal udara tersebut didaftarkan.

Barang yang diekspor kembali berbeda dengan barang yang diangkut terus atau diangkut lanjut. Secara formil, barang yang diangkut terus dan diangkut lanjut pada akhirnya memenuhi kaidah ekspor yaitu mengeluarkan barang dari dalam daerah pabean yang berarti setelah diimpor ${ }^{15}$ langsung diekspor ${ }^{16}$ kembali. Namun ada sebab substansi yang berbeda antara diangkut lanjut dan diangkut terus dengan diekspor kembali. Jika barang yang diangkut lanjut atau diangkut terus memang tidak ditujukan (not address to) suatu tempat di dalam daerah pabean, maka pada barang yang diekspor kembali pada hakikatnya memang ditujukan (address to) suatu tujuan di dalam daerah pabean Indonesia yang kemudian karena ada suatu hal terpaksa diekspor kembali. Halhal legal yang menyebabkan suatu barang diekspor kembali adalah:

a. pengiriman kembali barang impor keluar daerah pabean karena ternyata tidak sesuai dengan yang dipesan (retur);

b. oleh karena suatu ketentuan baru dari pemerintah tidak boleh diimpor ke dalam daerah pabean.

Di luar dari 2 alasan tersebut maka tidak disebut barang untuk diekspor kembali.

\footnotetext{
14 Pembongkaran yang berdampak pada keluarnya barang dari sarana pengangkut dan menjejak daratan/perairan Indonesia.

15 Impor dalam artian melintas masuk ke dalam, bukan impor dalam artian impor yang betul-betul impor

16 Ekspor dalam artian dikeluarkan sehingga terjadi pelintasan keluar.
} 
Hal tersebut karena secara bisnis memang ada orang mengimpor untuk kemudian diekspor kembali. Oleh karena itu hukum kepabeanan memfasilitasi dengan fasilitas KITE, kawasan bebas, kawasan berikat, ATA Carnet ${ }^{17}$, dan impor sementara.

\section{b. Ekspor}

Ekspor adalah kegiatan yang sangat dikenal oleh masyarakat umum. Namun ada perbedaan pengertian antara ekspor dalam konteks ekonomi bisnis dan impor menurut hukum kepabeanan Indonesia. Ekspor dalam konteks ekonomi bisnis adalah menjual barang ke luar negeri. ${ }^{18}$ Namun pada kenyataannya untuk kegiatan ekspor tidak selalu merupakan kegiatan menjual. Halhal lain yang bisa mengakibatkan timbulnya kepemilikan barang impor adalah hibah, meminjam, menyewa dan berbagai hubungan perikatan perdata lainnya. Oleh karena itu dalam hukum kepabeanan Indonesia, Ekspor adalah kegiatan mengeluarkan barang dari daerah pabean ${ }^{19}$. Penekanannya adalah pada kegiatan mengeluarkan ${ }^{20}$ yang berarti terjadi pelintasan ke luar daerah pabean.

\section{c. Intelijen}

17 Carnets, also known as "Passports for Goods" or "Merchandise Passports" are the easiest way to speed through Customs and to save money.The ATA Carnet is an international customs document that permits the dutyfree and tax-free temporary export and import of goods for up to one year. The Initials "ATA" are an acronym of the French and English words "Admission Temporaire/ Temporary Admission".

18 Pengalaman pribadi peneliti, sejak belajar di SD, pengertian bahwa ekspor adalah menjual barang ke luar negeri.

19 Daerah pabean adalah wilayah Republik Indonesia yang meliputi wilayah darat, perairan dan ruang udara di atasnya, serta tempat-tempat tertentu di Zona Ekonomi Eksklusif dan landas kontinen yang di dalamnya berlaku Undang-Undang ini (Pasal 1 angka 2 Undang-Undang Nomor 17 Tahun 2006 Tentang Perubahan UndangUndang Nomor 10 Tahun 1995 Tentang Kepabeanan).

20 Menurut kamus besar Bahasa Indonesia, memasukan berarti membawa (menyebabkan dan sebagainya) keluar; memindahkan sesuatu dari sebelah dalam ke sebelah luar: mengirimkan ke luar negeri; mengekspor
Kegiatan intelijen dilaksanakan oleh Unit Intelijen $^{21}$ dalam rangka pendeteksian dini atas pelanggaran. Kegiatan intelijen dilaksanakan dengan kegiatan pengelolaan informasi sesuai siklus intelijen, meliputi:

1) pengumpulan data atau informasi;

2) penilaian dan analisis data atau informasi;

3) pendistribusian data atau informasi; dan

4) evaluasi dan pemutakhiran data atau informasi.

Namun fungsi intelijen dalam pengelolaan informasi dalam pengawasan kepabeanan berkaitan dengan NPP (Narkotika, Psikotropika dan Prekursor Narkotika), dilaksanakan oleh Unit Narkotika. Unit Narkotika adalah unit pengawasan di lingkungan Direktorat Jenderal Bea dan Cukai yang melaksanakan tugas dan mempunyai fungsi intelijen dalam pengelolaan informasi berupa pengumpulan, penilaian, analisis, distribusi, dan evaluasi data atau informasi NPP serta penanganan penindakan dalam pelaksanaan upaya fisik yang bersifat administratif berupa patroli, penghentian, pemeriksaan, penegahan, penyegelan, dan penindakan lainnya dalam pengawasan kepabeanan berkaitan dengan Narkotika, Psikotropika dan Prekursor Narkotika.

Struktur unit intelijen Direktorat Jenderal Bea dan Cukai adalah:

1) Subdirektorat Intelijen pada Direktorat Penindakan dan Penyidikan.

2) Seksi Intelijen pada Kantor Wilayah, Kantor Wilayah Khusus dan Kantor Pelayanan Utama.

3) Subseksi Intelijen pada Kantor

\footnotetext{
21 Unit Intelijen adalah unit pengawasan di lingkungan Direktorat Jenderal Bea dan Cukai yang melaksanakan tugas dan mempunyai fungsi intelijen dalam pengelolaan informasi berupa pengumpulan, penilaian, analisis, distribusi, dan evaluasi data atau informasi berdasarkan database dan/atau informasi lainnya yang menunjukkan indikator risiko pelanggaran kepabeanan dan cukai. (Pasal 1 huruf c Perdirjen No P-53/BC/2010 Tentang Tata Laksana Pengawasan)
} 
Pengawasan dan Pelayanan Bea dan Cukai Tipe Madya Pabean, Tipe Madya Cukai, Tipe Madya Pabean A, Tipe Madya Pabean B, Tipe Madya Pabean C

Subseksi Penindakan dan Penyidikan pada Kantor Pengawasan dan Pelayanan Bea dan Cukai Tipe Pratama.

\section{d. Penindakan}

Penindakan terhadap barang dan/ atau sarana pengangkut serta bangunan atau tempat lain adalah suatu wewenang kepabeanan yang bersifat administratif dalam rangka menjamin hak-hak negara dan dipatuhinya ketentuan larangan dan pembatasan. Disadari bahwa penindakan tersebut tentunya akan menghambat kelancaran arus barang dan mengakibatkan keadaan yang kurang memuaskan bagi pemiliknya. Oleh karena itu, dalam pelaksanaannya dituntut kesadaran yang tinggi berdasarkan persyaratan yang ditetapkan dan bersifat objektif.

Pejabat Bea dan Cukai yang akan melaksanakan penindakan harus telah mempunyai petunjuk yang cukup atas tindakan yang akan diambilnya dan tetap mengutamakan tingkat pelayanan yang tinggi serta memberikan kepastian bagi pemilik barang dan orang yang dikenakan penindakan.

Setiap penindakan harus dapat dipertanggungjawabkan secara hukum berdasarkan alasan dan bukti yang cukup untuk mendapatkan penyelesaian akhir berupa penyidikan terhadap tindak pidana atau pengenaan sanksi administratif berupa denda atau penyerahan kembali kepada pemiliknya.

Penindakan meliputi:

1) Penghentian dan pemeriksaan terhadap sarana pengangkut;

2) Pemeriksaan terhadap barang, bangunan atau tempat lain, surat atau dokumen yang berkaitan dengan barang, atau terhadap orang;

3) Penegahan terhadap barang dan sarana pengangkut; dan

4) Penguncian, penyegelan, dan/atau pelekatan tanda pengaman yang diperlukan terhadap barang maupun sarana pengangkut.

Pejabat Bea dan Cukai berwenang melakukan penegahan terhadap :

1) Barang impor yang berada di Kawasan Pabean yang oleh pemiliknya akan dikeluarkan ke peredaran bebas tanpa memenuhi kewajiban pabean;

2) Barang impor yang keluar dari Kawasan Pabean yang berdasarkan petunjuk yang cukup belum memenuhi sebagian atau seluruh kewajiban pabeannya;

3) Barang ekspor yang berdasarkan petunjuk yang cukup belum memenuhi sebagian atau seluruh kewajiban pabeannya;

4) Sarana pengangkut yang memuat barang yang belum dipenuhi kewajiban pabeannya; atau

5) Sarana pengangkut yang belum diselesaikan kewajiban pabeannya.

Penegahan tidak dapat dilakukan terhadap :

1) Paket atau barang yang disegel oleh Penegak Hukum lain atau Dinas Pos;

2) Barang yang berdasarkan hasil pemeriksaan ulang atas Pemberitahuan atau Dokumen Pelengkap Pabean menunjukkan adanya kekurangan pembayaran Bea Masuk ${ }^{22}$;

3) Sarana pengangkut yang disegel oleh

22 Pemeriksaan ulang (verifikasi) terhadap Pemberitahuan atau Dokumen Pelengkap Pabean yang dilakukan oleh Kantor Pabean dapat mengakibatkan kekurangan pembayaran Bea Masuk yang telah dilakukan oleh importir/pemilik barang. Pelunasan kekurangan pembayaran Bea Masuk tersebut diselesaikan secara administratif. Namun demikian, ada kemungkinan bahwa barang impor tersebut masih berada di gudang importir yang bersangkutan. Terhadap barang yang bersangkutan tidak dapat dilakukan penegahan. 
Penegak Hukum lain atau Dinas Pos; atau

4) Sarana pengangkut Negara atau Negara Asing. ${ }^{23}$

\section{e. Penyidikan}

Dengan diundangkannya UU No. 10 Tahun 1995 stdd UU No. 17 Tahun 2006 tentang Kepabeanan dan UU No. 11 Tahun 1995 stdd UU No. 39 Tahun 2007 tentang Cukai, Pejabat Pegawai Negeri Sipil tertentu di lingkungan Direktorat Jenderal Bea dan Cukai diberi wewenang sebagai Penyidik untuk melakukan penyidikan tindak pidana di bidang Kepabeanan dan Cukai. Tindak pidana di bidang Kepabeanan dan Cukai adalah tindak pidana fiskal. Untuk menghadapi perkembangan dalam tindak pidana fiskal yang makin meningkat dari segi kuantitas maupun kualitasnya, diperlukan profesionalisme dalam penyidikan tindak pidana di bidang fiskal. Hal ini hanya dapat diwujudkan apabila dilaksanakan oleh pejabat yang secara khusus diberikan tugas untuk melakukan penyidikan. Guna mencapai efektivitas dan efisiensi dalam pelaksanaan penyidikan tindak pidana tersebut, penyidikannya dilaksanakan oleh Direktorat Jenderal Bea dan Cukai sebagai aparat yang bertanggung jawab dalam pelaksanaan UU No. 10 Tahun 1995 stdd UU No. 17 Tahun 2006 tentang Kepabeanan dan UU No. 11 Tahun 1995 stdd UU No. 39 Tahun 2007 tentang Cukai. Hal tersebut dipertegas dalam PP No. 55 Tahun 1996 Tentang "Penyidikan Tindak Pidana di Bidang Kepabeanan dan Cukai" pasal 1 ayat 1 yang berbunyi, "Penyidikan terhadap tindak pidana di bidang Kepabeanan dan

23 Yang dimaksud dengan "Sarana Pengangkut Negara" adalah pesawat Udara atau Kapal Laut yang dipergunakan oleh ABRI dan instasi pemerintah tertentu yang diberi fungsi dan kewenangan untuk menegakkan hukum sesuai dengan peraturan perundang-undangan yang berlaku. Ketentuan ini berlaku juga untuk sarana pengangkut negara asing milik Angkatan Bersenjata asing dan/ atau instansi pemerintah asing yang diberi fungsi dan kewenangan penegakan hukum atau pertahanan dan keamanan negara.
Cukai dilakukan oleh Penyidik Pegawai Negeri Sipil Direktorat Jenderal Bea dan Cukai".

Namun demikian dalam "situasi tertentu" penyidikan terhadap tindak pidana di bidang Kepabeanan dan Cukai dapat dilakukan oleh Penyidik Kepolisian Negara Republik Indonesia. Yang dimaksud dengan "dalam situasi tertentu" adalah keadaan yang tidak memungkinkan dilakukannya penyidikan oleh Penyidik Pegawai Negeri Sipil Direktorat Jenderal Bea dan Cukai karena hambatan geografis, keterbatasan sarana, atau tertangkap tangan oleh pejabat polisi negara Republik Indonesia untuk barang-barang yang dikeluarkan di luar Kawasan Pabean.

Dalam menjalankan tugasnya penyidik bea cukai diberi wewenang:

1) menerima laporan atau keterangan dari seseorang tentang adanya tindak pidana di bidang Kepabeanan;

2) memanggil orang untuk didengar dan diperiksa sebagai tersangka atau saksi;

3) meneliti, mencari, dan mengumpulkan keterangan dengan tindak pidana di bidang Kepabeanan;

4) melakukan penangkapan dan penahanan terhadap orang yang disangka melakukan tindak pidana di bidang Kepabeanan;

5) meminta keterangan dan bukti dari orang yang disangka melakukan tindak pidana di bidang Kepabeanan;

6) memotret dan/atau merekam melalui media audiovisual terhadap orang, barang, sarana pengangkut, atau apa saja yang dapat dijadikan bukti adanya tindak pidana di bidang Kepabeanan;

7) memeriksa catatan dan pembukuan yang diwajibkan menurut Undang-Undang ini dan pembukuan lainnya yang terkait;

8) mengambil sidik jari orang;

9) menggeledah rumah tinggal, pakaian, atau badan; 
10) menggeledah tempat atau sarana pengangkut dan memeriksa barang yang terdapat di dalamnya apabila dicurigai adanya tindak pidana di bidang Kepabeanan;

11) menyita benda-benda yang diduga keras merupakan barang yang dapat dijadikan sebagai bukti sehubungan dengan tindak pidana di bidang Kepabeanan;

12) memberikan tanda pengaman dan mengamankan apa saja yang dapat dijadikan sebagai bukti sehubungan dengan tindak pidana di bidang Kepabeanan;

13) mendatangkan tenaga ahli yang diperlukan dalam hubungannya dengan pemeriksaan perkara tindak pidana di bidang Kepabeanan;

14) menyuruh berhenti orang yang disangka melakukan tindak pidana di bidang Kepabeanan serta memeriksa tanda pengenal diri tersangka;

15) menghentikan penyidikan;

16) melakukan tindakan lain yang perlu untuk kelancaran penyidikan tindak pidana di bidang Kepabeanan menurut hukum yang bertanggung jawab.

Namun demikian mengingat penyidikan tersebut adalah penyidikan atas tindak pidana di bidang fiskal, maka untuk kepentingan penerimaan negara, atas permintaan Menteri Keuangan, Jaksa Agung dapat menghentikan penyidikan tindak pidana di Bidang Kepabeanan. Penghentian penyidikan tindak pidana di bidang Kepabeanan tersebut hanya bisa dilakukan setelah yang bersangkutan melunasi Bea Masuk yang tidak atau kurang dibayar, ditambah dengan sanksi administrasi berupa denda empat kali jumlah Bea Masuk yang tidak atau kurang dibayar.

\section{B. Struktur dan Kedudukan Bea Cukai Dalam Ranah Tata Negara}

Direktorat Jenderal Bea dan Cukai adalah salah satu unit eselon I di Kementerian Keuangan. Kedudukan Direktorat Jenderal Bea dan Cukai sejajar dengan Sekretariat Jenderal, Direktorat Jenderal Anggaran, Direktorat Jenderal Pajak, Direktorat Jenderal Perbendaharaan, Direktorat Jenderal Kekayaan Negara, Direktorat Jenderal Perimbangan Keuangan, Direktorat Jenderal Pengelolaan Pembiayaan dan Risiko, Inspektorat Jenderal, Badan Kebijakan Fiskal, Badan Pendidikan dan Pelatihan Keuangan, Staf Ahli Bidang Peraturan dan Penegakan Hukum Pajak, Staf Ahli Bidang Kepatuhan Pajak, Staf Ahli Bidang Pengawasan Pajak, Staf Ahli Bidang Kebijakan Penerimaan Negara, Staf Ahli Bidang Pengeluaran Negara, Staf Ahli Bidang Makro Ekonomi dan Keuangan Internasional, Staf Ahli Bidang Kebijakan dan Regulasi Jasa Keuangan dan Pasar Modal dan Staf Ahli Bidang Organisasi, Birokrasi, dan Teknologi Informasi.

Direktorat Jenderal Bea dan Cukai adalah adalah unsur pelaksana tugas pokok dan fungsi Kementerian Keuangan di bidang kepabeanan dan cukai. Sedangkan kepabeanan adalah Kepabeanan adalah "segala sesuatu yang berhubungan dengan pengawasan atas lalu lintas barang yang masuk atau keluar daerah pabean serta pemungutan bea masuk dan bea keluar". Daerah pabean sendiri didefinisikan sebagai "wilayah Republik Indonesia yang meliputi wilayah darat, perairan dan ruang udara di atasnya, serta tempat-tempat tertentu di Zona Ekonomi Eksklusif dan landas kontinen yang di dalamnya berlaku UU No. 10 tahun 1995 stdd UU No. 17 Tahun 2006 Tentang Kepabeanan". Artinya Direktorat Jenderal Bea dan Cukai adalah unsur pelaksana tugas pokok dan fungsi Kementerian Keuangan yang berwenang menangani "segala sesuatu yang berhubungan dengan pengawasan atas 
lalu lintas barang yang masuk atau keluar wilayah Republik Indonesia yang meliputi wilayah darat, perairan dan ruang udara di atasnya, serta tempat-tempat tertentu di Zona Ekonomi Eksklusif dan landas kontinen".

Sebagai unit eselon I di Kementerian Keuangan tentu Bea Cukaitidak bisa langsung luwes melakukan perubahan khususnya transformasi kelembagaan melainkan harus melalui restu Menteri Keuangan. Sementara organisasi Kementerian Keuangan sudah sangat gemuk dengan diisi 17 Eselon I di luar Bea Cukai.

Perubahan organisasi adalah hal yang tidak dihindarkan lagi. Hal tersebut berdampak pada perubahan struktur organisasi. DJBC merupakan unit eselon I Kementerian Keuangan, oleh karena itu ketika hendak mengubah struktur organisasinya perlu terlebih dahulu mendapatkan izin Menteri Keuangan yang tertuang pada Peraturan Menteri Keuangan.

Perubahan organisasi di DJBC sangatlah dinamis. Hal tersebut dibuktikan dengan 2 PMK terakhir yang berdekatan temponya yaitu Peraturan Menteri Keuangan Nomor 168/PMK.01/2012 Tentang Organisasi dan Tata Kerja Instansi Vertikal Direktorat Jenderal Bea dan Cukai. Dalam tempo 2 tahun langsung terbit lagi PMK Nomor 206.3/PMK.01/2014 Tentang Perubahan Atas Peraturan Menteri Keuangan Nomor 168/PMK.01/2012 Tentang Organisasi dan Tata Kerja Instansi Vertikal Direktorat Jenderal Bea dan Cukai.

Tugas dan fungsi Direktorat Jenderal Bea dan Cukai seperti yang tertuang dalam Peraturan Menteri Keuangan (PMK) Nomor 206/PMK.01/2014 Tentang Organisasi dan Tata Kerja Kementerian Keuangan. Dalam rangka melaksanakan tugas dan fungsi tersebut, Direktur Jenderal (Dirjen) Bea dan Cukai didukung oleh 10 (sepuluh) Unit Eselon 2 di lingkungan Kantor Pusat sebagai berikut:

1) Sekretariat Direktorat Jenderal;

2) Direktorat Teknis Kepabeanan;

3) Direktorat Fasilitas Kepabeanan;

4) Direktorat Cukai;

5) Direktorat Penindakan dan Penyidikan;

6) Direktorat Audit;

7) Direktorat Kepabeanan Internasional;

8) Direktorat Penerimaan dan Peraturan Kepabeanan dan Cukai;

9) Direktorat Informasi Kepabeanan dan Cukai; dan

10) Pusat Kepatuhan Internal Kepabeanan dan Cukai

Masing-masing unit eselon 2 memiliki tugas dan fungsi yang berbeda-beda dan spesifik. Sekretariat Jenderal sebagai unsur pembantu Pimpinan memiliki tugas untuk melaksanakan koordinasi pelaksanaan tugas, pembinaan, dan pemberian dukungan administrasi kepada seluruh unit organisasi di lingkungan Direktorat Jenderal Bea dan Cukai. Sedangkan masing-masing Direktorat sebagai unsur pelaksana memiliki tugas untuk merumuskan serta melaksanakan kebijakan dan standardisasi teknis di bidangnya masing-masing. Adapun Pusat Kepatuhan Internal mempunyai tugas untuk melaksanakan fungsi pengawasan internal di lingkungan Direktorat Jenderal Bea dan Cukai.

Di lingkungan Direktorat Jenderal Bea dan Cukai juga terdapat Tenaga Pengkaji yang bertugas untuk memberikan telaahan kepada Direktorat Jenderal Bea dan Cukai mengenai masalah-masalah di bidang pelayanan dan penerimaan kepabeanan dan cukai, pengawasan dan penegakan hukum kepabeanan dan cukai, dan pengembangan kapasitas dan kinerja organisasi. Tenaga Pengkaji terdiri atas 3 (tiga) orang Tenaga Pengkaji yakni:

1) Tenaga Pengkaji Bidang Pelayanan 
dan Penerimaan Kepabeanan dan Cukai;

2) Tenaga Pengkaji Bidang Pengawasan dan Penegakan Hukum Kepabeanan dan Cukai; dan

Tenaga Pengkaji Bidang
Pengembangan Kapasitas dan
Kinerja Organisasi.

Selain unit eselon 2 diatas, Direktorat Jenderal Bea dan Cukai juga memiliki instansi vertikal. Berdasarkan Peraturan Menteri Keuangan Nomor 168/PMK.01/2012 Tentang Organisasi dan Tata Kerja Organisasi Vertikal Direktorat Jenderal Bea dan Cukai, Direktorat Jenderal Bea dan Cukai terdiri atas Kantor Wilayah (Kanwil), Kantor Pelayanan Utama (KPU), Kantor Pengawasan dan Pelayanan (KPP) yang tersebar di seluruh wilayah Indonesia. Sampai dengan saat ini, Direktorat Jenderal Bea dan Cukai memiliki 16 (enam belas) Kantor Wilayah dengan satu Kantor Wilayah yang bersifat khusus yaitu Kantor Wilayah DJBC Khusus Kepulauan Riau. Kantor wilayah membawahi Kantor Pengawasan dan Pelayanan, Pangkalan Sarana Operasi dan Balai Pengujian dan Identifikasi Barang. Kantor Pengawasan dan Pelayanan terdiri dari 6 (enam) tipe Kantor Pengawasan dan Pelayanan Bea dan Cukai (KPPBC) Tipe Madya Pabean, KPPBC Tipe Madya Cukai, KPPBC Tipe Madya Pabean A, KPPBC Tipe Madya Pabean B, KPPBC Tipe Madya Pabean C dan KPPBC Tipe Pratama. Setiap KPPBC dapat membawahkan Kantor Bantu Pelayanan Bea dan Cukai dan/atau Pos Pengawasan Bea dan Cukai.

Berdasarkan PMK Nomor 206.3/ PMK.01/2014 Tentang Perubahan Atas Peraturan Menteri Keuangan Nomor 168/ PMK.01/2012 Tentang Organisasi dan Tata Kerja Organisasi Vertikal Direktorat Jenderal Bea dan Cukai, Kantor Pelayanan Utama terdiri dari 3 (tiga) tipe, yaitu Kantor Pelayanan Utama Tipe A, Kantor Pelayanan Utama Tipe B dan Kantor
Pelayanan Utama Tipe C. Setiap KPU dapat membawahi Kantor Bantu Pelayanan Bea dan Cukai dan/atau Pos Pengawasan Bea dan Cukai. Berdasarkan PMK Nomor 206.3/ PMK.01/2014, Bea Cukai memiliki 3 Kantor Pelayanan Utama, 117 Kantor Pengawasan dan Pelayanan Bea dan Cukai, 148 Kantor Bantu, 692 Pos Pengawasan.

Disamping itu, Direktorat Jenderal Bea dan Cukai juga memiliki kelompok jabatan fungsional yang tugasnya sesuai dengan jabatan fungsional masing-masing berdasarkan peraturan perundangundangan.

Dari hasil diagnosa organisasi DJBC dalam program transformasi kelembagaan, secara umum didapatkan sejumlah tantangan di bidang kelembagaan yang membatasi DJBC dalam menyelenggarakan kegiatan operasionalnya secara efektif dan efisien, yaitu:

a. Terbatasnya kapasitas untuk mendorong perubahan/terbatasnya kapasitas untuk melakukan transformasi kelembagaan, yang ditandai dengan tidak adanya unit yang secara khusus fokus pada pengendalian dan harmonisasi inisiatif-inisiatif strategis transformasi kelembagaan yang dilakukan oleh seluruh unit eselon II di lingkungan DJBC;

b. Terbatasnya kapasitas pengambilan keputusan yang strategis di lingkungan DJBC, yang antara lain ditandai dengan tersitanya waktu pimpinan DJBC pada hal-hal yang bersifat administratif dan kurangnya waktu untuk memikirkan hal yang bersifat strategis;

c. Rentang kendali yang terlampau besar di tingkat Eselon I yang membawahi 31 pejabat eselon II (termasuk Kepala Kantor Wilayah dan Kepala Kantor Pelayanan Utama Bea dan Cukai). 


\section{Kesimpulan dan Saran}

1. Kesimpulan

a. Pelaksanaan Penegakan Hukum oleh Bea Cukai Terkait Kejahatan Transnasional

Pelaksanaan penegakan hukum oleh bea cukai dilakukan dengan 2 cara yaitu melalui pengawasan dan pelayanan. Pengawasan adalah upaya aktif petugas untuk memastikan bahwa ketentuan kepabeanan telah dipenuhi. Adapun pelayanan adalah upaya petugas untuk melayani upaya para subjek hukum untuk memenuhi kewajiban hukumnya. Karena melayani adalah suatu kegiatan yang timbul bila ada kepentingan dari pihak yang dilayani maka kegiatan pelayanan senantiasa cenderung pasif.

Pengawasan bisa dimaknai secara umum atau secara khusus. Secara umum, pengawasan adalah segala sesuatu yang dilakukan dalam rangka memastikan dan menjamin terpenuhinya ketentuan undang-undang kepabeanan. Pengawasan kepabeanan secara khusus adalah dilakukan dengan cara intelijen, penindakan dan penyidikan.

Pelayanan kepabeanan dilakukan dengan 2 cara yaitu kegiatan pelayanan dalam rangka impor dan dalam rangka ekspor. Kegiatan pelayanan dalam rangka impor adalah untuk melayani kegiatankegiatan untuk memasukan barang ke dalam daerah pabean. Adapun kegiatan pelayanan ekspor adalah kegiatan pelayanan untuk mengeluarkan barang ke luar daerah pabean. Dengan kegiatan pengawasan dan pelayanan kepabeanan itulah kejahatan transnasional dapat terdeteksi dan termitigasi.

b. Struktur dan Kedudukan Bea Cukai Dalam Ranah Tata Negara

Direktorat Jenderal Bea dan Cukai adalah salah satu unit eselon I di Kementerian Keuangan. Kedudukan Direktorat Jenderal Bea dan Cukai sejajar dengan Sekretariat Jenderal, Direktorat Jenderal Anggaran, Direktorat Jenderal
Pajak, Direktorat Jenderal Perbendaharaan, Direktorat Jenderal Kekayaan Negara, Direktorat Jenderal Perimbangan Keuangan, Direktorat Jenderal Pengelolaan Pembiayaan dan Risiko, Inspektorat Jenderal, Badan Kebijakan Fiskal, Badan Pendidikan dan Pelatihan Keuangan, Staf Ahli Bidang Peraturan dan Penegakan Hukum Pajak, Staf Ahli Bidang Kepatuhan Pajak, Staf Ahli Bidang Pengawasan Pajak, Staf Ahli Bidang Kebijakan Penerimaan Negara, Staf Ahli Bidang Pengeluaran Negara, Staf Ahli Bidang Makro Ekonomi dan Keuangan Internasional, Staf Ahli Bidang Kebijakan dan Regulasi Jasa Keuangan dan Pasar Modal dan Staf Ahli Bidang Organisasi, Birokrasi, dan Teknologi Informasi.

Sebagai unit eselon I di Kementerian Keuangan tentu Bea Cukaitidak bisa langsung luwes melakukan perubahan khususnya transformasi kelembagaan melainkan harus melalui restu Menteri Keuangan. Sementara organisasi Kementerian Keuangan sudah sangat gemuk dengan diisi 17 Eselon I di luar Bea Cukai.

\section{Saran}

Dari kesimpulan yang telah diambil maka dapat diajukan beberapa saran yaitu:

a. Guna mencapai efektivitas dan efisiensi dalam pelaksanaan tugas hendaknya Direktorat Jenderal Bea Cukai dipisahkan dari Kementerian Keuangan dan dibentuk badan tersendiri sejajar dengan Kementerian Keuangan yang bertanggung jawab langsung kepada Presiden.

b. Guna menyiasati kelemahan sarana dan prasarana maka kualitas pegawai bea cukai harus ditingkatkan dengan meningkatkan tingkat pendidikan baik melalui tugas belajar maupun melalui pelatihan diklat-diklat untuk mengembangkan kompetensi pelaksanaan tugas. Dengan harapan 
meski ada kekurangan sarana prasarana, pelaksanaan tugas tetap terlaksana dengan baik karena keunggulan SDM.

c. Guna mengantisipasi hambatanhambatan di masa depan (khususnya hambatan hukum) maka perlu dilakukan evaluasi terhadap undang-undang kepabeanan (UU No. 10 Tahun 1995 stdd UU No. 17 Tahun 2006 ) yang sudah sekitar 10 tahun dijalankan. Evaluasi tersebut diharapkan dapat menguatkan Bea Cukai secara kelembagaan yang pada akhirnya berdampak pada optimalnya kinerja Bea Cukai khususnya dalam menghadapi kejahatan transnasional.

\section{DAFTAR PUSTAKA}

\section{A. BUKU}

Adrian Sutedi. 2012. Aspek Hukum Kepabeanan. Jakarta: Sinar Grafika.

Ali Purwito M. 2013. Kepabeanan Indonesia: Konsep, Kebijakan dan Penerapan. Tangerang Selatan: Jelajah Nusa.

Barda Nawawi Arief. 1994. Kebijakan Legislatif Dalam Penanggulangan Kejahatan Dengan Pidana Penjara. Yogyakarta: Genta Publising.

Buchari Alma, 2010, Pengantar Bisnis, Bandung: Alfabeta.

Direktorat Jenderal Bea dan Cukai, Lakin (Laporan Kinerja) 2014, Kementerian Keuangan, Jakarta.

Direktorat Jenderal Bea dan Cukai, Renstra (Rencana Strategi) 2015-2019, Kementerian Keuangan, Jakarta.

Eddhi Sutarto. 2011. Reformasi Sistem Hukum dan Kebijakan Kepabeanan di Indonesia: Studi tentang Rekonstruksi Reformasi Kepabeanan di Indonesia. Disertasi UNDIP. Semarang.

I Wayan Parthiana. 2004. Hukum Pidana Internasional dan Ekstradisi.
Bandung: Yrama Widya.

Nico Ngani, 2012, Metodologi Penelitian dan Penulisan Hukum, Pustaka Yustitia, Yogyakarta.

Oentoeng Wahjoe, 2011, Perkembangan Tindak Pidana Internasional dan Proses Penegakannya, Jakarta: Penerbit Erlangga.

Padmo Wahyono, 1986, Indonesia Negara Berdasarkan Atas Hukum, Jakarta: Ghalia Indonesia.

Peter Mahmud Marzuki. 2005. Penelitian Hukum Edisi Revisi. Jakarta; Prenadamedia Group.

Romli Atmasasmita, 1995, Pengantar Hukum Pidana Internasional. Bandung: PT. Eresco.

Romli Atmasasmita, 1997, Tindak Pidana Narkotika Transnasional dalam Sistem Hukum Pidana Indonesia, Bandung: Citra Aditya Bhakti.

Satdjipto Raharjo. 2009. Masalah Penegakan Hukum Suatu Tinjauan Sosiologis. Bandung: Sinar Baru.

Serian Wjatno dan Ariawan Gunadi, 2014, Perdagangan Bebas dalam Perspektif Hukum Perdagangan Internasional, Jakarta: PT. Grasindo.

Shinta Agustina. 2006. Hukum Pidana Internasional (Dalam Teori dan Praktek). Padang: Andalas University Press.

Surono, 2015, Fasilitas Kepabeanan $A$ to $Z$, Jakarta: PT. Pro Insani Cendekia.

Yudi Wibowo Sukinto. 2013. Tindak Pidana Penyelundupan di Indonesia: Kebijakan Formulasi Sanksi Pidana. Jakarta: Sinar Grafika.

B. PERATURAN

PERUNDANGUNDANGAN

Undang-Undang Dasar Negara Republik Indonesia Tahun 1945 
Kitab Undang-Undang Hukum Pidana

Undang-Undang Nomor 8 Tahun 1981

Tentang Hukum Acara Pidana

UU No. 17 Tahun 2006 Tentang Perubahan UU No. 10 Tahun 1995 Tentang Kepabeanan.

UU No. 39 Tahun 2007 Tentang Perubahan UU No. 11 Tahun 1995 Tentang Cukai.

Undang-Undang Nomor 5 Tahun 2009

Tentang Pengesahan United

Nations Convention Against

Transnational Organized Crime

(Konvensi Perserikatan Bangsa-

Bangsa Menentang Tindak Pidana

Transnasional yang Terorganisasi).

Peraturan Pemerintah Nomor 21 Tahun 1996 tentang Penindakan Di Bidang Kepabeanan

Peraturan Pemerintah Nomor 55 Tahun 1996 tentang Penyidikan Tindak Pidana Di Bidang Kepabeanan dan Cukai

Peraturan Pemerintah Nomor 49 Tahun 2009 tentang Tata Cara Penindakan di Bidang Cukai

Keputusan Menteri Keuangan Republik Indonesia Nomor 30/KMK.05/1997 tanggal 16 Januari 1997 Tentang Tatalaksana Penindakan Di Bidang Kepabeanan

Keputusan Menteri Keuangan Republik Indonesia Nomor: 92/KMK.05/1997 tentang Pelaksanaan Penyidikan Tindak Pidana di Bidang Kepabeanan dan Cukai

Peraturan Menteri Keuangan nomor 238/ PMK.04/2009 tanggal 30 Desember 2009 tentang Tata Cara Penghentian, Pemeriksaan, Penegahan, Penyegelan,Tindakan Berupa Tidak Melayani Pemesanan Pita Cukai atau Tanda Pelunasan Cukai Lainnya, dan Bentuk Surat Perintah Penindakan
Cukai nomor 08/BC/1997 tentang Penghentian, Pemeriksaan, dan Penegahan Sarana Pengangkut dan Barang diatasnya serta Penghentian Pembongkaran dan Penegahan Barang

Keputusan Direktur Jenderal Bea dan Cukai nomor 37/BC/1997 tentang Pemeriksaan barang, Bangunan, atau Tempat lain dan Surat atau Dokumen yang Berkaitan dengan Barang

Keputusan Direktur Jenderal Bea dan Cukai nomor 38/BC/1997 tentang Pemeriksaan Badan

Keputusan Direktur Jenderal Bea dan Cukai nomor 57/BC/1997 tentang Petunjuk Pelaksana Proses Penyidikan Tindak Pidana di Bidang Kepabeanan dan Cukai

Keputusan Direktur Jenderal Bea dan Cukai nomor 101/BC/2001 tentang Petunjuk Pelaksanaan Penindakan dan Penyidikan di Bidang Kepabeanan dan Cukai pada Direktorat Penindakan dan Penyidikan

Peraturan Direktur Jenderal Bea dan Cukai Nomor P- 53 /BC/2010 Tentang Tatalaksana Pengawasan

\section{LAIN-LAIN}

www.politikindonesia.com

www.detik.com

www.republika.co.id

Direktorat Jenderal Bea dan Cukai, www. beacukai.go.id

Kementerian Keuangan, www.depkeu.go.id

Direktorat Jenderal Bea dan Cukai, www. beacukai.go.id

Direktorat Jenderal Pajak, www.pajak.go.id

Direktorat Jenderal Perbendaharaan, www. djpbn.go.id dan www.perbendaharaan.go.id

Majalah Warta Bea Cukai

Buletin Berkala LPSK Edisi No. III Tahun 
2012

Enny Soeprapto. 2007. Kejahatan Perang, Kejahatan Terhadap Kemanusiaan dan Kejahatan Genosida sebagai Kejahatan Internasional: Beberapa Catatan. Makalah yang disampaikan dalam sosialisasi Peradilan HAM, Kerjasama Komnas HAM dengan FH UNPAD tanggal 5 Juni 2007.

Bandung.

Dokumen terbatas World Bank, Indonesia: Policies for Growth and Employment, report no. 5597-Ind., 23 April 1985

Dokumen terbatas International Monetary Fund, Indonesia-Recent Economic Development, 10 Mei 1985

TEMPO edisi April 1972

TEMPO edisi 11 April 1987 